\title{
Cytokine Receptor
}

National Cancer Institute

\section{Source}

National Cancer Institute. Cytokine Receptor. NCI Thesaurus. Code C17667.

A cytokine receptor is a protein on the cell surface that specifically binds cytokine lig ands which are small proteins secreted by immune cells. These receptors mediate molecular functions such as signal transduction. 